\title{
Trust in Green Advertising: Mediating Role of Environmental Involvement
}

\section{Poh-Kiong Tee, Kim-Yew Lim, Chee-Pung Ng, Ling-Chai Wong}

To Link this Article: http://dx.doi.org/10.6007/IJARBSS/v12-i1/12046 DOI:10.6007/IJARBSS/v12-i1/12046

Received: 12 November 2021, Revised: 16 December 2021, Accepted: 05 January 2022

Published Online: 25 January 2022

In-Text Citation: (Tee et al., 2022)

To Cite this Article: Tee, P.-K., Lim, K.-Y., Ng, C.-P., \& Wong, L.-C. (2022). Trust in Green Advertising: Mediating Role of Environmental Involvement. International Journal of Academic Research in Business and Social Sciences, 12(1), 1771-1786.

\section{Copyright: @ 2022 The Author(s)}

Published by Human Resource Management Academic Research Society (www.hrmars.com)

This article is published under the Creative Commons Attribution (CC BY 4.0) license. Anyone may reproduce, distribute, translate and create derivative works of this article (for both commercial and non0-commercial purposes), subject to full attribution to the original publication and authors. The full terms of this license may be seen at: http://creativecommons.org/licences/by/4.0/legalcode

Vol. 12, No. 1, 2022, Pg. 1771- 1786

Full Terms \& Conditions of access and use can be found at http://hrmars.com/index.php/pages/detail/publication-ethics 


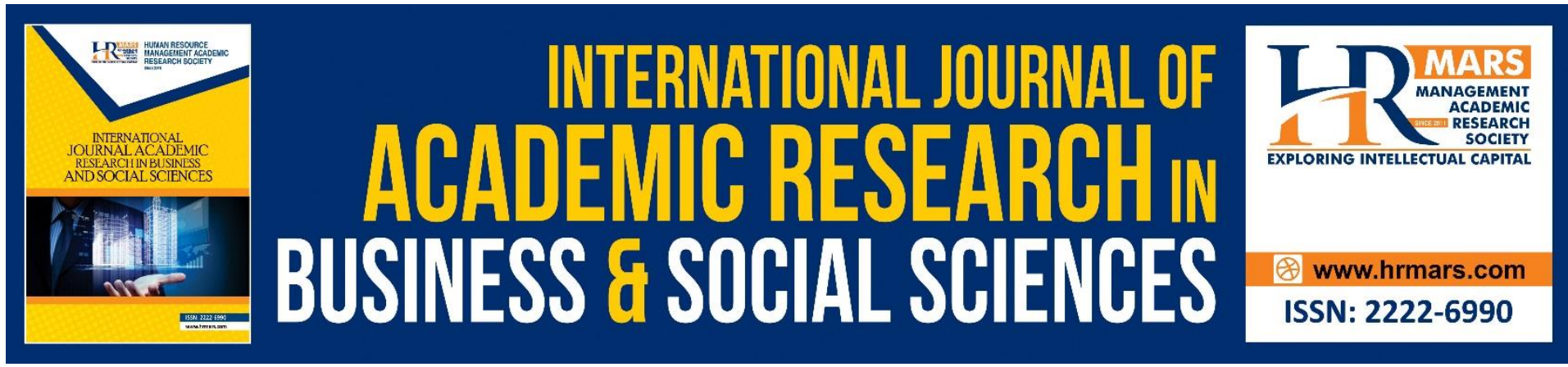

\title{
Trust in Green Advertising: Mediating Role of Environmental Involvement
}

\author{
Poh-Kiong Tee \\ Asia Pacific University of Technology and Innovation, Malaysia \\ Email: seantee@live.com \\ Kim-Yew Lim, Chee-Pung Ng \\ INTI International University, Malaysia \\ Email: kylim71@gmail.com,cpng101@hotmail.com \\ Ling-Chai Wong \\ Asia Pacific University of Technology and Innovation, Malaysia \\ Email: wong.lingchai@apu.edu.my
}

\begin{abstract}
The Covid-19 pandemic has heightened public interest and awareness of the importance of living sustainably while sparked interest in businesses that make "good" use of their green marketing campaign. Indeed, green marketing has gained wide acceptance within the business world as a viable competitive strategy to grab and win customers' attention in the marketplace. This research sought to investigate how the green advertising environmental claims affect consumers' trust in the green advertisement. The mediating role of involvement was examined. Data from 185 respondents in Malaysia were collected and analysed using SPSS. Adapted scales were used to measure environmental claims, environmental involvement, and trust and their relationships were tested using PROCESS macro and SPSS. The findings revealed that environmental claims had a significant direct and indirect effect on consumers' trust via environmental involvement. Environmental involvement partially mediated the relationship between environmental claims and consumers' trust toward the green advertisement. Results indicate that environmental claims did enhance consumers' trust in green advertisements. Moreover, consumers with deep environmental concerns had higher trust in the green advertisement if the advertising (environmental) claims included relevant facts and were executed correctly. The results of this study can be used as a reference for future research of consumers' attitudes toward green marketing/advertising and the types of advertising execution in green marketing. Furthermore, the findings of this study also add to the growing body of knowledge about green marketing in developing countries like Malaysia, which has a large potential market for green products. This study is limited to only two constructs, many variables such as advertising's execution techniques and media strategies can be included for future research directions.
\end{abstract}


Keywords: Environmental claims, Environmental involvement, Green advertisement, Scepticism

\section{Introduction}

Since the Covid-19 pandemic, there has been a surge in environmental, social, and governance (ESG). The epidemic has heightened public awareness of the importance of living sustainably. Economic operations have been halted or reduced due to restrictive measures such as lockdowns and movement restriction orders (Dass, 2021). It has, however, sparked interest in businesses/investments that make "good" use of their investment in green and sustainability marketing campaigns. The pace of green businesses/marketing and demand for green consumption has gained momentum. Concurrently, environmental pollution has emerged as one of the most severe worldwide concerns in the era of industrial development (Pandey \& Singh, 2019), and people have repeatedly introduced dangerous pollutants into the environment at an alarming rate (Manisalidis et al., 2020). According to a WHO report (http://www.who.int/), household consumption is responsible for around $60 \%$ of global gas emissions and $80 \%$ of polluted water usage. Nonetheless, consumers' environmental concerns are becoming more prominent in their purchase decisions.

The environmental issues have raised global concern among society, particularly for marketers. Green marketing has gained wide acceptance within the business world as a viable competitive strategy to grab and win customers' attention in the marketplace (Liao et al., 2020; Wang et al., 2020). Hence, comprehending consumers and developing green marketing strategies to entice targeted consumers have become common research topics. Past studies showed that many companies have begun implementing green marketing strategies to meet consumers' needs and gain a larger market for green products to achieve long-term business profits (Dangelico \& Vocalelli, 2017; Sdrolia \& Zarotiadis, 2019; Zhuang et al., 2021). Similarly, environmental issues have become a new scenario for the businesses in Malaysia to participate in green activities as part of their social responsibility and transformation programme (Aslam et al., 2020; Ahmed et al., 2017).

The concept of green marketing is gaining traction, necessitating more efforts to promote environmentally friendly products (Liao et al., 2020; Mo et al., 2018). Green marketing is based on the assumption that people will perceive green attributes as a benefit and significant value, resulting in positive attitudes and purchase behaviour for green products compared to traditional, non-green products (Bukhari, 2011; Dangelico \& Vocalelli, 2017). In the context of green marketing, marketers use green advertising to communicate the "green" positioning in the minds of customers (Eren-Erdogmus et al., 2016). Advertisements addressing environmental concerns are always found positively related to consumers attitudes towards green products and their intention to be friendly to the environment (Kim et al., 2019). Indeed, most scholars agreed on the crucial roles of green advertising in marketing; nevertheless, regarding the effectiveness of environmental claims in advertising on consumers' perception (i.e., trust) on green advertisement remain unclear (Kao \& Du, 2020; Kong \& Zhang, 2014; Wang et al., 2020).

Advertisement is a persuasive strategy used by marketers to convince customers to purchase their goods and services (Sun et al., 2020; Tee et al., 2019). Thus, advertisers will make numerous assertions to promote, publicise, and persuade potential customers to buy or consume the advertised products (Belch \& Belch, 2021). Although an increase in green offerings and demands has been observed, there is also a high level of concern among consumers about companies conveying false and misleading environmental claims to improve 
the company's sales and reputation (Goh \& Balaji, 2016). Nevertheless, given the vast profit margins connected with green marketing, some companies have been discovered to exaggerate or even manipulate information about their products' environmental worth (Hussain et al., 2020); this practice is known as "greenwashing". Undeniably, some marketers attempt to exploit "green" practices by making unsubstantiated or misleading claims about a firm's environmental impact in their advertisement (Hussain et al., 2020; Schmuck et al., 2018). As a result, consumers might find green advertising is mistrustful and interpret it as vague or misleading. Schmuck et al (2018) stated that environmental attributes embedded with the products are hard to verify, thus makes consumers lose their confidence and trust in green advertisements. Moreover, some companies might exaggerate their dedication to mitigating the negative environmental impact of their operations to improve their reputation for sustainability practice (Chen, 2013; Wang et al., 2020). The customers might have doubts and disbelieve the environmental claims made by the companies, and this phenomenon is referred to as "green scepticism".

Trust plays a vital role in the study of advertising and consumer behaviour because the trustworthiness of advertisement may affect consumers' purchase intention (Chia et al., 2019; Ulusoy \& Barretta, 2016), while the truthfulness of advertising claims may determine the quality and effectiveness of the advertising message (Hussain et al., 2020). Typically, consumers gain trust in the environmental claims in advertisements based on their rational information processing towards the advertising appeals and execution. If consumers found the environmental claims and promises of the green advertisement are lacking in truth, their purchase intention will be negatively affected. Nevertheless, those consumers who are more environmentally conscious are generally sceptical about the environmental claims of green advertisement because many advertisers are said to engage in greenwashing (Musgrove et al., 2018; Nyilasy et al., 2012; Rahim et al., 2019). Therefore, gaining trust is a crucial criterion for advertisers to build and enhance trusting relationships with customers in which green claims are not something that both parties can compromise.

With this background, this study aims to explore the effect of environmental claims in green advertising on consumers' trust toward the green advertisement. Past studies also revealed that environmentally conscious or involved consumers are generally more sceptical about the environmental claims to determine their attitudes toward the advertisement or brand (Nyilasy et al., 2012; Rahim et al., 2019, Ulusoy \& Barretta, 2016). This study further investigates whether consumer involvement may heighten or reduce (i.e., mediate) the consumers' trust toward the environmental claims in the green advertisement. This study could help understand the influencing factors of consumers' trust in green advertisements and the changing mechanism of consumers' trust under involvement. The results of this study can be used as a reference for future research of consumers' attitudes toward green marketing/advertising and the types of advertising execution in green marketing, which is helpful for marketers who would like to pursue green marketing. Furthermore, this study intends to add to the growing body of knowledge about green consumer trust in developing countries, particularly in Malaysia, which has a large potential market for green products (Rahim et al., 2019; The Star, 2019).

\section{Literature Review}

This paper explores the construct of advertising (environmental) claims and the mediation impact of consumers' environmental involvement toward consumers' trust in the green advertisement. Using Elaboration Likelihood Model (ELM: Petty \& Cacioppo, 1986) to 
underpin the present study, the researchers would like to testify the impact of environmental claims and consumer involvement as they link with trust in the green advertisement. ELM studied the influence of persuasive techniques on the individual's attitude formation (Petty $\&$ Cacioppo, 1986). There are two levels of interpretation towards the presented information: the central route and the peripheral route (Petty \& Cacioppo, 1986). Moreover, "involvement" and "issue relevancy" also displayed influence over the elaboration continuum. Research suggests that a central route of ELM (i.e., environmental claims in this study) was associated with higher involvement and issue relevancy. In contrast, a lower degree of involvement and issue relevancy may have been attributed to the peripheral route of ELM (Durmaz et al., 2016). Thus, the authors expected that consumer involvement might mediate the relationship between environmental claims and trust in the green advertisement.

\section{Trust in Green Advertisement}

With a massive apprehension of environmental pollution, many marketers have actively engaged in sustainability development by developing and promoting green products. The incidence of green advertising has increased in many developing countries, and consumers have been exposed to various environmental claims in the advertisement. The terms such as sustainability, recycling, and environmentally friendly have become common appeals in green marketing targeted at households and industries. Most companies use green advertising to promote green products or services by conveying the relationship between the product and the environment and enhancing the corporate image of environmental responsibility (Krstić et al., 2021; Liao et al., 2020; Tee et al., 2014). Kumar (2017) claimed that green advertising aims to inform consumers about a company's environmental practices, build trust in environmental promises, and engage with customers.

In the context of green marketing, marketers tend to convey information about its environmental vision and mission, "green" operating practices, along ethical code of conduct to attract consumers' attention to green products. It is crucial for a green advertisement to be trustable to develop a positive perception among customers (Yoon \& Kim, 2016). Hence, trust is viewed as an essential criterion for a successful relationship. Consumers are more willing to engage in a relationship with an honest and trustable brand, whereas businesses should refrain from opportunistic practices to gain the trust of their customers to avoid losing faith in their brands (Sun et al., 2019; Ulusoy \& Barretta, 2016). Moreover, trust in advertising is vital; if people find the information provided in the advertisement is reliable and trustable, they are willing to act according to the message conveyed in the advertisement (Dhanesh \& Nekmat, 2019; Ebrahim, 2019; Shieh et al., 2018). It is significant to study the determinants of consumer trust in the corporations' advertisement considering the consumers constantly establish scepticism regarding the advertising messages. Therefore, this study explores approaches to gaining consumer trust from the perspective of psychological resilience.

\section{Environmental Claims and Trust in Green Advertisement}

Advertising claims refer to the informativeness, objectivity, concreteness, and quality of advertising messages. Consumer responses to advertising are influenced by the claims provided in an advertisement (Belch \& Belch, 2021; Gangadharbatla et al., 2020). Research results show that advertising claim affects consumer responses to advertising (Prasad et al., 2017; Wang et al., 2020). Despite the fact that environmental advertising has been the subject 
of much research, the green advertising claim itself has rarely been probed. Among the very few researches on green advertising claims, Musgrove et al (2018) examined the impacts of different green advertising claim types (i.e., product-oriented, process-oriented, image-oriented, and environmental). They found a significant interaction between green advertising claim types and corporate credibility on consumer scepticism. Prasad et al (2017) noted that advertising claims could be classified into search, experience, and credence claims. The environmental claim that is considered as credence claim is the most difficult to verify, but it is widely used in green advertising to influence the consumers' trust toward the advertisement. Chan et al (2006) also reported that the superiority of environmental claims generates greater communication effectiveness. Particularly the consumers have more favourable attitudinal responses toward the advertisement and the brand.

Nevertheless, in the context of green advertising, the environmental-related information is often vague, leading consumers to perceive the information as greenwashing (Grebmer \& Diefenbach, 2020; Kamguna \& Li, 2017; Zhang et al., 2021), and thus affect the consumers' trust toward green advertisements. As most consumers found environmental claims in the green advertisement are challenging to comprehend and hard to verify. The inconsistencies in the advertising environmental claims with the companies' "green" practices result in consumers being sceptical towards green advertisements (Goh \& Balaji, 2016; Rahman et al., 2015; Sun et al., 2019). Consequently, losing trust in green advertisement (Paco \& Reis, 2012; Srivastava, 2017). A study on the consumer perception toward green advertising in India found that a wide variation of claim types in green advertising and the increasing greenwashing trend make customers feel sceptical toward green advertisement (Prasad et al., 2017).

Some studies discovered that due to the inconsistency between green marketing strategies and advertising claims, consumers lack trust and confidence in the environmental claims, which prevents them from purchasing green products (Joshi \& Rahman, 2015; Yu, 2020). Krstić et al. (2021) conducted an extensive literature review of the effectiveness of green advertising in terms of execution characteristics, environmental claims, and greenwashing. The strength of environmental claims appears to be a relevant factor in advertising effectiveness. However, the effectiveness of green advertisement is put into question mostly due to the appearance of consumers' scepticism, and the general scepticism (i.e., lack of trust) regarding green advertising has been confirmed in literature (Atkinson \& Rosenthal 2014; Leonidou \& Skarmeas, 2017; Ulusoy \& Barretta, 2016). Segev's (2015) quantitative content analysis of green advertisements from 18 popular and environmental magazines from 2009 and 2010 found an increase in green advertisements due to the growing consumer demand for green products in the past 20 years. Besides, consumers' scepticism about green advertising was justified, but the environmental claims are trending toward being more acceptable than misleading compared to 20 years ago (Segiv, 2015).

In sum, advertising (environmental) claims have an impact on consumer trust toward the green advertisement. If consumers feel the environmental claims and promises lack truth, consumers' trust in the green advertisement will be negatively affected and vice versa. The following hypothesis is proposed to testify to this relationship.

$\mathrm{H} 1$ : There is a significant relationship between environmental claims in green advertising and consumers' trust in green advertisements. 


\section{Environmental Involvement}

Many past studies postulated significant empirical support regarding the impact of environmental claims toward green advertising effectiveness (i.e., trust). Indeed, the effectiveness is also mediated by many factors, and one of them was involvement (Krstić et al., 2021; Rahim et al., 2019, Ulusoy \& Barretta, 2016). The concept of involvement is often taken into consideration in understanding consumer behaviour. Extant studies suggested that consumers have different responses to persuasive messages according to their level of involvement (Matthes \& Wonneberger, 2014; Parguel et al., 2015; Petty \& Cacioppo, 1986; Schmuck et al., 2018). The action-reason-involvement (ARI) model affirmed the mediating role of consumers' involvement by revealing that consumers' involvement may heighten or lower the effect of rational and affective persuasion towards advertising effectiveness.

Similarly, ELM postulated that the process by which the audiences form their attitudes toward the advertising messages or advertised product/brand is mediated by an individual's level of involvement with an advertising message (Petty \& Cacioppo, 1986). The earlier research examined the mediating role of consumers' involvement in consumers' response to green advertisements and found that highly involved consumers demonstrated more concern on cognitive, environmental claims than low-involved consumers (Schuhwerk \& LefkoffHagius, 1995). D'Souza and Taghian (2005) compared the impact of consumers' involvement on their cognitive and affective responses towards advertisements. Lower involved customers have a more vigorous disregard for green advertising in both cognitive and affective responses.

Schmuck et al (2018) postulated two types of environmental involvements in green advertising that can influence the consumers' trust in the advertising claims: environmental concerns and environmental knowledge. Shin et al (2017) suggested that consumers are more responsive to green advertising when highly involved with pro-environmental issues. Patel and Chugan (2015) noticed that consumers with deep environmental concerns had more ability and interest to evaluate the credibility of environmental claims. Those with higher environmental knowledge are more likely to distinguish false claims in advertisements. They can quickly identify misleading advertising and mistrust the green advertisement (Schmuck et al., 2018). Similarly, high environmental concern consumers were found more concerned about the "green" claims and scepticism if they encounter "greenwashing" practices (Grebmer \& Diefenbach, 2020).

The majority of research in environmental studies found that, in general, more environmentally concerned consumers are more sceptical toward green claims presented in advertising (Alamsyah et al., 2020; Do Paço \& Reis, 2012; Krstić et al., 2021; Ulusoy \& Barretta, 2016). Different responses toward green communication might be generated due to different levels of environmental involvement. It is crucial to consider the impact of involvement along with the link between environmental claims and trust towards green advertisement. In this study, the environmental claims are chosen as subject matter that construes trust towards green advertisement. Also, this study aims to probe the mediating role of environmental involvement in greater detail to enhance our understanding of this under-researched topic. Therefore, the following hypothesis was proposed:

$\mathrm{H} 2$ : Environmental involvement mediates the relationship between environmental claims and consumers' trust toward the green advertisement.

In this study, the environmental claim is assumed to be the key predictor for consumers' trust in green advertisements. As another influential factor, environmental 
involvement is included as a mediating mechanism along the direct paths to provide insights into the predictive values of environmental claims in the green advertisement. The research framework is reported in Figure 1.

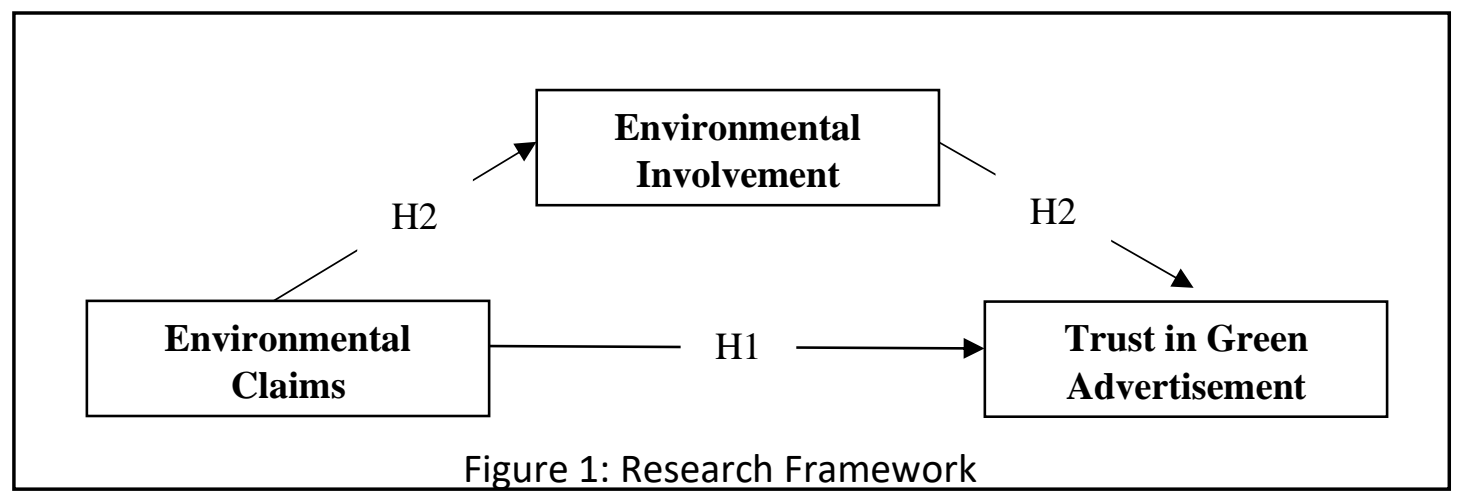

\section{Methodology \\ Participants}

Data were collected from the respondents among Millennials and Gen X in Malaysia. The online survey was conducted due to the movement control order in Malaysia during data collection. One hundred eighty-five responses were received. The sample comprised 99 $(53.5 \%)$ men and 80 (43.2\%) women, who were aged $23-30$ years $(30.3 \%), 31-38$ years $(20 \%)$, $39-46$ years (22.2\%), and $47-54$ years (27.6\%). Approximately half of the respondents $(49.7 \%)$ held a bachelor's degree, while $33 \%$ held a master's degree, $14.6 \%$ held a diploma, and other qualifications only accounted for $2.7 \%$.

\section{Instruments}

Three latent constructs were proposed, and the relationships among them were tested. The measures for these constructs were mainly adapted from previous tested and validated scales. Environmental claims are measured using Tariq's (2014) green advertising scales, phrased as, "Green advertising effectively addresses environmental problems". The measures for environmental involvement were adapted from the scales developed by Kronrod et al. (2012), phrased as, "Environmental issues are important to me". Trust was measured by the scale established by Chen and Chang (2013), phrased for example, as, "I believe that the advertisement's environmental claims are generally trustworthy". Respondents were asked to rate their perception on the four latent constructs using a Fivepoint Likert scale ranging from ' $1=$ strongly disagree' to ' $5=$ strongly agree'. Besides, Cronbach's alpha was tested to check the reliability of the questions for each construct. Cronbach's alpha value for all instruments was above 0.70 (from 0.77 to 0.817 ), indicating the questionnaire's reliability (Sekaran \& Bougie, 2016).

\section{Data Analysis}

Statistical Package for Social Sciences (SPSS) version 25.0 was used to analyse the data, including Hayes' (2013) PROCESS analysis for estimating the mediation models. Hayes (2013) conditional process analysis is known as an integration of mediation and moderation analysis to understand the conditional nature of the mediation (or moderation) mechanism, which was found suitable to explain the estimation of the mediation model in this study. 


\section{Results}

\section{Conditional Process Analysis}

Figure 2 illustrates the mediation model tested using the SPSS PROCESS macro model number 4 (Hayes, 2013).

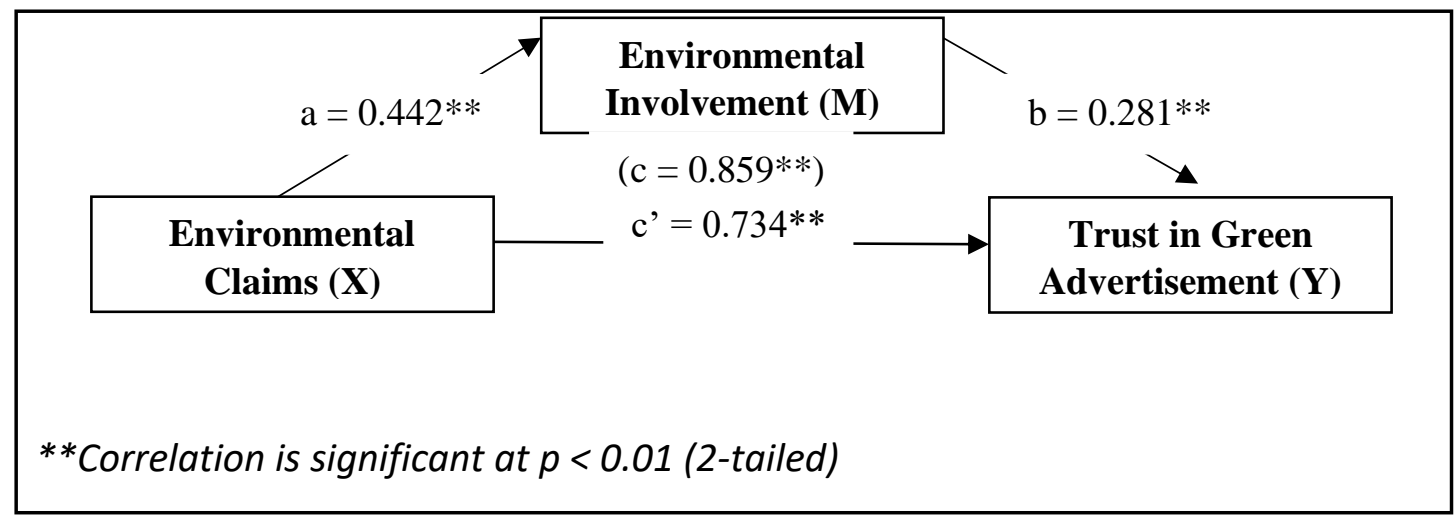

Figure 2: Mediation Model

Table 1 displays the results of the regression and mediation analysis. First, the results of the regression analysis show that the environmental claims (independent variable) were a significant predictor of environmental involvement $(\beta=0.442, t=7.824, p<0.01)$. While controlling for environmental claims (mediator), the results of the second regression analysis show that environmental claims are also a significant predictor of trust in green advertisement (dependent variable: $\beta=0.734, t=10.821, p<0.01$ ).

Table 1 also reported the independent variable's direct, indirect, and total effects on the dependent variable. A 95\% bias-corrected confidence interval based on 5,000 bootstrap samples indicated that the indirect effect of involvement $(a * b=0.124)$ was entirely above zero $(\mathrm{Cl}=0.045$ to 0.211$)$. Since zero is not within the $\mathrm{Cl}$, this indicates a significant mediating effect of environmental involvement (Hayes, 2013). Moreover, the mediator, environmental involvement, accounted for approximately $15 \%(0.124 / 0.858)$ of the total effect on consumers' trust.

Table 1: Results of Regression and Mediation Analysis

\begin{tabular}{|c|c|c|c|c|c|c|}
\hline \multirow[t]{2}{*}{ Path } & \multirow[t]{2}{*}{ Std. Beta } & \multirow[t]{2}{*}{ Std. Error } & \multirow[t]{2}{*}{ t-value } & \multirow[t]{2}{*}{$P$} & \multicolumn{2}{|c|}{$95 \% \mathrm{Cl}$} \\
\hline & & & & & $\mathrm{LLCl}$ & ULCI \\
\hline $\mathrm{CL} \rightarrow \mathrm{TRU}$ & .734 & .068 & 10.821 & .000 & .601 & .868 \\
\hline $\mathrm{CL} \rightarrow \mathrm{INV}$ & .442 & .056 & 7.824 & .000 & .330 & .553 \\
\hline INV $\rightarrow$ TRU & .281 & .076 & 3.679 & .000 & .130 & .431 \\
\hline \multicolumn{7}{|l|}{ Effects } \\
\hline Direct & .734 & .068 & 10.821 & .000 & .601 & .868 \\
\hline Indirect & .124 & .043 & & & .045 & .211 \\
\hline Total & .858 & .061 & 14.107 & .000 & .739 & .978 \\
\hline
\end{tabular}

Note. $\mathrm{CL}=$ Environmental claim, INV = Environmental involvement, $\mathrm{TRU}=$ Trust on advertisement 


\section{Discussion}

This study was undertaken to understand better consumers' perceptions of green advertising (environmental) claims and their trust toward the green advertisement. The findings supported $\mathrm{H} 1$ and $\mathrm{H} 2$, which proposed a direct impact of environmental claims on consumers' trust toward the green advertisement and indirect impact (i.e., mediation) via environmental involvement. The finding reported a substantial $(\beta=0.734)$ positive impact of environmental claims on consumer's trust towards green advertising. This finding indicates that environmental claims are the main predictor to enhance consumers' trust towards the green advertisement. This finding is in line with the positive effect of the advertising environmental claims in green advertisement (Prasad et al., 2017; Sahin et al., 2019; Segev et al., 2016; Wang et al., 2020). It appears that consumers' trust in the green advertisement is much affected by the extent to which green advertising claims, specifically, environmental claims that are perceived to be informative and valuable. The strength of advertising claims; clear and specific environmental claims appear to be the most relevant factor of advertising effectiveness (Krstić et al., 2021; Rooijmans, 2018; Ulusoy \& Barretta, 2016). Some researchers found that vague environmental claims are perceived as greenwashing and deteriorate consumers' attitudes toward advertisements and brands (Majláth, 2017; Parguel et al., 2015; Schmuck et al., 2018). However, Chen and Chiu (2016) explored the advertising claims of "abstract/concrete messages" in green advertising. They found those environmentally conscious (i.e., high-involved) consumers are more responsive to abstract messages, whereas less environmentally conscious consumers do not demonstrate different reactions to different types of messages. That mean, consumers' responses toward green advertisements also depend on their environmental consciousness/involvement.

Interestingly, this study also presented evidence for an indirect effect of perceived environmental claims on trust towards green advertisements through the construct of environmental involvement. The concept of involvement is taken into consideration in this study in line with the literature in advertising and communication management, suggested that consumers have different reactions to persuasive messages according to their level of involvement (Matthes \& Wonneberger, 2014; Parguel et al., 2015; Petty \& Cacioppo, 1986; Schmuck et al., 2018). Concurred with Grebmer and Diefenbach's (2020) findings, the significant role of environmental involvement was testified, and consumers with high environmental involvement were found more concerned about advertising claims and more sceptical when they encounter environmental claims in the green advertisement. This, in turn, translates into an increased or decreased level of green trust. Several studies (Alamsyah et al., 2020; Chen \& Chiu, 2016; Krstić et al., 2021; Ulusoy \& Barretta, 2016) explored the importance of environmental involvement (i.e., awareness, concerns and consciousness) in green advertising. They provide strong empirical evidence that consumers did respond differently to green communication in forming their attitudes towards green advertisements and brands.

The significant complementary mediation effects of consumers' involvement in this study can be explained by increasing environmental consciousness on consumer behaviour in today's market context (Parguel et al., 2015; Peattie \& Belz, 2010). There is a general consensus within the business and consumer communities that a large majority of consumers are concerned about the environmental issues during their purchase and consumption. Moreover, the finding in this study also showed that approximately $85 \%$ of the respondents (with $\mu=3.97$ ) are highly involved or concerned with the environmental issues, thus, are more responsive to the environmental claims in determining their trust toward the green advertisement. 


\section{Implications}

Theoretically, the results have implications for the role of advertising (environmental) claims in the green advertisement by reinforcing prior findings and offering several new insights. Prior studies have established concreteness of advertising (environmental) claims as an antecedent of trust in the green advertisement. This paper expands on that with a more comprehensive model of green advertising, which includes consumer involvement as the mediating mechanism along the direct path. The results provide evidence for a partial (complementary) mediating effect of involvement between environmental claims and trust. A vital realisation regarding this indirect effect is that the environmental involvement was mediated the impact of claims towards trust on the green advertisement. However, only a weak mediating effect (approximately 15\%) was found. This result demonstrates that involvement is not a sufficient precondition but only a mediator for consumers' trust in green advertisements. The relationship between advertising claims and trust in the green advertisement is more complex than previously assumed. Regardless of their involvement, the consumers could detect the truthfulness of environmental claims, which can be attributed to a generally higher level of trust towards green advertisement.

Practically, this study offers insights on how to manage green advertising and communications campaigns. Since advertising claims substantially impact consumers' trust towards green advertisements, the claims should be detailed with more factual information to instigate consumers' trust toward green advertising and communications (Shieh et al., 2018). Results also imply that consumers with different levels of involvement had different responses to environmental claims. Thus, advertisers or marketing practitioners should consider the environmental behaviour of consumers in order to formulate effective communication strategies for green advertising. Furthermore, to prevent the increase in greenwashing practices, policymakers should issue several revisions of its communications and multimedia content regulations to ensure continued reliable standards of advertisements. These regulations aim to avoid misleading environmental claims in advertising and communications and ensure the advertising claims are truthful, not deceptive.

\section{Limitations and Conclusion}

This study explores the relationship between environmental claims, environmental involvement and trust towards green advertisement among consumers in Malaysia. Generalisations of these findings are expectedly limited in two respects. First, we took into account only two constructs, one predictor and one mediator, to predict consumers' trust in this study. Many variables can be included in this framework, such as advertising's execution techniques, media strategies and audiences' knowledge and preferences, but are not considered. Second, the sample consisted only of respondents from Millennials and Gen $\mathrm{X}$ in Malaysia; as a result, meaningful remarks could only be made about these two categories. It does limit the generalizability of the results for all consumers in Malaysia.

In conclusion, despite limitations, the results can provide some theoretically and practically implications whereby advertisers should focus on the advertising content to gain consumers' trust towards green advertisement.

\section{References}

Ahmed, M. I., Kamalanabhan, T. J., \& Chih, P. L. G. (2001). Green marketing and its implications on consumers and business in Malaysia - An empirical study. Journal of Human Ecology, 12(4), 245-249. https://doi.org/10.1080/09709274.2001.11907611 
Alamsyah, D. P., Othman, N. A., \& Mohammed, H. A. A. (2020). The awareness of environmentally friendly products: The impact of green advertising and green brand image. Management Science Letters, 10(9), 1961-1968. http://dx.doi.org/10.5267/j.msl.2020.2.017

Aslam, W., Farhat, K., \& Arif, I. (2020). Regular to sustainable products: an account of environmentally concerned consumers in a developing economy. International Journal of Green Energy, 18, 243 - 257. http://dx.doi.org/10.1080/15435075.2020.1854266

Atkinson, L., \& Rosenthal, S. (2014). Signalling the green sell: The influence of eco-label source, argument specificity, and product involvement on consumer trust. Journal of Advertising, 43(1), 33-45. http://dx.doi.org/10.1037/t48423-000

Belch, G., \& Belch, M. (2021). Advertising and promotion: An integrated marketing communications perspective, 12th Edition. McGraw Hill.

Bukhari, S. S. (2011). Green marketing and its impact on consumer behaviour. European Journal of Business and Management, 3(4), 375-383.

Chan, R., Leung, T. K. P., \& Wong, Y. H. (2006). The effectiveness of environmental claims for services advertising. Journal of Services Marketing, 20(4), 233-250. http://dx.doi.org/10.1108/08876040610674580

Chen, Y. S., \& Chang, C. H. (2013). Greenwash and green trust: The mediation effects of green consumer confusion and green perceived risk. Journal of Business Ethics, 114, 489500. http://dx.doi.org/10.1007/s10551-012-1360-0

Chen, M. Y., \& Chiu, C. I. (2016). Go green: How to influence the perceived effectiveness of a green product? International Journal of Advertising, 35(4), 622-641. https://doi.org/10.1080/02650487.2015.1105647

Chia, K. M., Rohizan, A., Tee, P. K., and Tajuddin, A. R. (2019). Evaluation of service quality dimensions toward customers' satisfaction of ride-hailing services in Kuala Lumpur Malaysia. International Journal of Recent Technology \& Engineering, 7(5S), 102-109.

Dangelico, R. M., \& Vocalelli, D. (2017). Green marketing: An analysis of definitions, strategy steps, and tools through a systematic review of the literature. Journal of Cleaner Production, 165, 1263-1279. https://doi.org/10.1016/J.JCLEPRO.2017.07.184

Dass, A. (2021). The Star. Greenwashing could be the next risk for ESG. https://www.thestar.com.my/business/businessnews/2021/05/17/greenwashingcould-be-the-next-risk-for-esg

Dhanesh, G. S., \& Nekmat, E. (2019). Facts over stories for involved publics: Framing effects in CSR messaging and the roles of issue involvement, message elaboration, affect, and skepticism. Management Communication Quarterly, 33(1), 7-38. https://doi.org/10.1177\%2F0893318918793941

Do Paço, A. M. F., \& Reis, R. (2012). Factors affecting skepticism toward green advertising. Journal of advertising, 41(4), 147-155. https://doi.org/10.1080/00913367.2012.10672463

D'Souza, C., \& Taghian, M. (2005). Green advertising effects on attitude and choice of advertising themes. Asia Pacific Journal of Marketing and Logistics, 17(3), 51-66. http://dx.doi.org/10.1108/13555850510672386

Durmaz, G., Suher, K., \& Bir, C. (2015). Elaboration likelihood model (ELM) in print advertisements: A content analysis of advertisements which is positioned in special and general interest magazines. Journal of Yaşar University, 11(41), 45-56. http://dx.doi.org/10.19168/jyu.00944 
Ebrahim, R. (2019). The role of trust in understanding the impact of social media marketing on brand equity and brand loyalty. Journal of Relationship Marketing, 19, 1-22. http://dx.doi.org/10.1080/15332667.2019.1705742

Eren-Erdogmus, I., Lak, H. S., \& Çiçek, M. (2016). Attractive or credible celebrities: who endorses green products better? Procedia - Social and Behavioral Sciences, 235, 587-594. http://doi.org/10.1016/j.sbspro.2016.11.085

Gangadharbatla, H., Vardeman, C., \& Quichocho, D. (2020). Investigating the reception of broad versus specific CSR messages in advertisements in an environmental context. Journal of Marketing Communications. 1-19. https://doi.org/10.1080/13527266.2020.1857818.

Goh, S. K., \& Balaji, M. S. (2016). Linking green skepticism to green purchase behaviour. Journal of Cleaner Production, 131, 629-638.

http://dx.doi.org/10.1016/j.jclepro.2016.04.122

Grebmer, C., \& Diefenbach, S. (2020). The challenges of green marketing communication: effective communication to environmentally conscious but skeptical consumers. Designs, 4(3), https://doi.org/10.3390/designs4030025

Hayes, A. F. (2013). Introduction to mediation, moderation, and conditional process analysis: A regression-based approach. Guilford Press.

Hussain, S., Melewar, T. C., Priporas, C. V., \& Foroudi, P. (2020). Examining the effects of advertising credibility on brand credibility, corporate credibility and corporate image: A qualitative approach. Qualitative Market Research, 23(4), 549-573. https://doi.org/10.1108/QMR-12-2017-0175

Joshi, Y., \& Rahman, Z. (2015). Factors affecting green purchase behaviour and future research directions. International Strategic management review, 3(1-2), 128-143. https://doi.org/10.1016/j.ism.2015.04.001

Kamguna, R., \& Li, Y. (2017). Misleading environmental claims and their impacts on consumer purchase intention.: A quasi-experimental study [Online] Available at: https://www.diva-portal.org/smash/record.jsf?pid=diva2:1112136

Kao, T. F., \& Du, Y. Z. (2020). A study on the influence of green advertising design and environmental emotion on advertising effect. Journal of Cleaner Production, 242. https://doi.org/10.1016/j.jclepro.2019.118294

Kim, W. H., Malek, K., \& Roberts, K. R. (2019). The effectiveness of green advertising in the convention industry: an application of a dual coding approach and the norm activation model. Journal of Hospitality and Tourism Management, 39, 185-192.

Kong, Y., \& Zhang, L. (2014). When does green advertising work? The moderating role of product type. Journal of Marketing Communication, 20(3), 197-213. https://doi.org/10.1080/13527266.2012.672335

Kronrod, A., Grinstein, A., \& Wathieu, L. (2012). Go green! Should environmental messages be so assertive? Journal of Marketing, 76, 95-102. https://doi.org/10.1509\%2Fjm.10.0416

Krstić, J., Kostic-Stankovic, M., \& Cvijovic, J. (2021). Green advertising and its impact on environmentally friendly consumption choices: A review. Industrija. 49. 93-110. https://doi.org/10.5937/industrija49-31692

Kumar, P. (2017). Intents of green advertisements. Asia Pacific Journal of Marketing and Logistics, 29(1), 70-79. http://dx.doi.org/10.1108/APJML-03-2016-0044

Leonidou, C. N., \& Skarmeas, D. (2017). Gray shades of green: causes and consequences of green scepticism. Journal of Business Ethics, 144(2), 401-415. https://link.springer.com/article/10.1007\%2Fs10551-015-2829-4 
Liao, Y. K., Wu, W. Y., \& Pham, T. T. (2020). Examining the moderating effects of green marketing and green psychological benefits on customers' green attitude, value and purchase intention. Sustainability, 12(18), 1-19. http://dx.doi.org/10.3390/su12187461

Majláth, M. (2017) The effect of greenwashing information on ad evaluation. European Journal of Sustainable Development, 6(3), 92-99. https://doi.org/10.14207/ejsd.2017.v6n3p92

Manisalidis, I., Stavropoulou, E., Stavropoulos, A., \& Bezirtzoglou, E. (2020). Environmental and health impacts of air pollution: A review. Front. Public Health, 8(14). https://doi.org/10.3389/fpubh.2020.00014

Matthes, J., \& Wonneberger, A. (2014). The skeptical green consumer revisited: Testing the relationship between green consumerism and scepticism toward advertising. Journal of Advertising, 43 (2), 115-127. http://dx.doi.org/10.1080/00913367.2013.834804

Mo, Z., Liu, M.T., \& Liu, Y. (2018). Effects of functional green advertising on self and others. Psychology \& Marketing, 35(5), 368-382. https://doi/abs/10.1002/mar.21092

Musgrove, C. C. F., Choi, P., \& Chris, C. K. (2018). Consumer perceptions of green marketing claim: An examination of the relationships with the type of claim and corporate credibility. Services Marketing Quarterly, 39(4), 277-292. https://doi.org/10.1080/15332969.2018.1514794

Nyilasy, G., Gangadharbatla, H., \& Paladino, A. (2012). Greenwashing: A consumer perspective. Economics \& Sociology, 5(2), 116-154. https://www.proquest.com/scholarly-journals/greenwashing-consumerperspective/docview/1268704693/se-2?accountid=46

Paço, A. M. F. D., \& Reis, R. (2012). Factors affecting skepticism toward green advertising. Journal of advertising, 41(4), 147-155. https://doi.org/10.1080/00913367.2012.10672463

Pandey, V. C., \& Singh, V. (2019). Exploring the potential and opportunities of current tools for removal of hazardous materials from environments. In V.C., Pandey, (Eds.), Phytomanagement of Polluted Sites, (pp. 501-516). Elsevier.

Parguel, B., Benoît-Moreau, F., \& Russell, C. A. (2015). Can evoking nature in advertising mislead consumers? The power of 'executional greenwashing'. International Journal of Advertising, 34(1), 107-134. https://doi.org/10.1080/02650487.2014.996116

Patel, C., \& Chugan, P. K. (2015). The influence of consumer perception towards green advertising on green purchase intention. International Journal of Entrepreneurship \& Business Environment Perspectives, 4(3), 1865-1873.

https://ssrn.com/abstract $=2683918$

Peattie, K., \& Belz, F. M. (2010). Sustainability marketing - An innovative conception of marketing. Marketing Review St. Gallen, 27, 8-15. http://dx.doi.org/10.1007/s11621010-0085-7

Petty, R. E., \& Cacioppo, J. T. (1986). The elaboration likelihood model of persuasion. Advances in Experimental Social Psychology, 19, 123-205. http://dx.doi.org/10.1016/S0065-2601(08)60214-2

Prasad, M., Mishra, T., Kalro, A. D., \& Bapat, V. (2017). Environmental claims in Indian print advertising: An empirical study and policy recommendation. Social Responsibility Journal, 13(3), 473-490. https://doi.org/10.1108/SRJ-05-2016-0091

Rahim, M. H. A., Zukni, R. Z. J. A., Ahmad, F., \& Lyndon, N. (2019). Green advertising and environmentally responsible consumer behavior: the level of awareness and 
perception of Malaysian youth. Asian Social Science, 8(5), 46-57. https://doi.org/10.5539/ass.v8n5p46

Rahman, I., Park, J., \& Chi, C. G. Q. (2015). Consequences of "greenwashing" consumers' reactions to hotels' green initiatives. International Journal of Contemporary Hospitality Management, 27(6), 1054-1081.

http://www.gatrenterprise.com/GATRJournals/index.html

Rooijmans, T. (2018). Gaining trust through greenness: How green advertising messages translate into green trust for varying degrees of social distance. [Master's thesis, Radboud University], Nijmegen

Sahin, S., Baloglu, S., \& Topcuoglu, E. (2019). The influence of green message types on advertising effectiveness for luxury and budget hotel segments. Cornell Hospitality Quarterly, 61(4), 1-18. https://doi.org/10.1177\%2F1938965519892189

Schmuck, D., Matthes, J., \& Naderer, B. (2018). Misleading consumers with green advertising? An affect-reason-involvement account of greenwashing effects in environmental advertising. Journal of Advertising, 47(2), 127-145. https://doi.org/10.1080/00913367.2018.1452652

Schuhwerk, M. E., \& Lefkoff-Hagius, R. (1995). Green or non-green? Does type of appeal matter when advertising a green product? Journal of Advertising, 24(2), 45-54. https://doi.org/10.1080/00913367.1995.10673475

Sdrolia, E., \& Zarotiadis, G. (2019). A comprehensive review for green product term: From definition to evaluation. Journal of Economic Surveys, 33(1), 150-178. http://dx.doi.org/10.1111/joes.12268

Segev, S., Fernandes, J., \& Hong, C. (2016). Is your product really green? A content analysis to reassess green advertising. Journal of Advertising, 45(1), 85-93. https://doi.org/10.1080/00913367.2015.1083918

Sekaran, U., \& Bougie, R. (2016). Research methods for business: A skill-building approach. John Wiley \& Sons.

Shin, S., Ki, E. J., \& Griffin, W. G. (2017). The effectiveness of fear appeals in 'green' advertising: An analysis of creative, consumer, and source variables. Journal of Marketing Communications, 23(5), 473-492. https://doi.org/10.1080/13527266.2017.1290671

Shieh, M. D., Chen, C. N., \& Lin, M. C. (2018). Discussion of correlations between green advertising design and purchase intention based on consumers' environmental attitude. Ecology, 27(106), 1153-1159.

http://www.ekolojidergisi.com/download/discussion-of-correlations-betweengreen-advertising-design-and-purchase-intention-based-on-5423.pdf

Srivastava, V. (2017). Exploring skepticism toward green advertising: An ISM approach. International Journal of Business Analytics and Intelligence, 5(1), 3-17. http://www.ischolar.in/index.php/ijbai/article/view/138778

Sun, Y., Luo, B., Wang, S., \& Fang, W. (2019). What you see is meaningful: Does green advertising change the intentions of consumers to purchase eco-labelled products? Business Strategy and the Environment, 30(1), 694-704. https://doi.org/10.1002/bse.2648

Tariq, M. Z. (2014). Impact of green advertisement and green brand awareness on green satisfaction with mediating effect of buying behaviour. Journal of managerial sciences, 8(2), 274-289. 
Tee, P. K., Eaw, H. C., Oh, S. P., and Han, K. S. (2019). The employability of Chinese graduate in Malaysia upon returning to China employment market. International Journal of Recent Technology \& Engineering, 8(2S), 358-365.

Tee, P. K., Gharleghi, B., \& Chan, Y. F. (2014). E-Ticketing in airline industries among Malaysian: the determinants. International Journal of Business \& Social Science, 5(9), 168-174

The Star. (2019). Green products are gaining traction. Available at: https://www.thestar.com.my/business/smebiz/2019/05/27/green-products-gainingtraction

Ulusoy, E., \& Barretta, P. G. (2016). How green are you, really? Consumers' skepticism toward brands with green claims. Journal of Global Responsibility, 7(1), 72-83. https://doi.org/10.1108/JGR-11-2015-0021

Wang, D., Walker, T., \& Barabanov, S. (2020). A psychological approach to regaining consumer trust after greenwashing: The case of Chinese green consumers. Journal of Consumer Marketing, 37(6), 593-603. https://doi.org/10.1108/JCM-06-2019-3257

World Health Organisation. (WHO). Air Pollution. Available online at: http://www.who.int/airpollution/en/

Yoon, H. J., \& Kim, Y. J. (2016). Understanding green advertising attitude and behavioural intention: An application of the health belief model. Journal of promotion management, 22(1), 49-70. http://dx.doi.org/10.1080/10496491.2015.1107006

$\mathrm{Yu}$, J. (2020). Consumer responses toward green advertising: The effects of gender, advertising skepticism, and green motive attribution. Journal of Marketing Communications, 26(4), 414-433. https://doi.org/10.1080/13527266.2018.1514317

Zhang, X., Shao, X., Jeong, E., \& Jang, S. C. (2021). The effects of restaurant green demarketing on green skepticism and dining intentions: Investigating the roles of benefit associations and green reputation. International Journal of Hospitality Management, 97(97), http://dx.doi.org/10.1016/j.ijhm.2021.103007

Zhuang, W., Luo, X., \& Riaz, M. U. (2021). On the factors influencing green purchase intention: A meta-analysis approach. Frontiers in Psychology, 12.

https://doi.org/10.3389/fpsyg.2021.644020 